J. Product. \& Dev., 20(3): 285 - 296(2015)

\title{
DEVELOPMENT OF HAPLOID PLANTS THROUGH ANTHER CULTURE TECHNIQUE IN WHEAT ( Triticum aestivum L. )
}

\author{
H. A. Abo Shama ; Y. M. Yaseen and Hala. S. Ghareeb
}

Plant Biotech Dept . Genet. Engin. and Biotech .Res. Inst ( GEBRI), Sadat

City, University Menufiya, Egypt.

\section{ABSTRACT}

Anther culture was utilized to develop haploid plants in wheat .This study was carried out at Plant Biotechnology Department, Genetic Engineering and Biotechnology Research Institute ( $G E B R$ I) from 2009 to 2014 years. Three varieties of wheat were used, Sids1, Gemmeiza 9 and Giza 168. The studied factors were, cold and chemical pretreatments, growth regulators concentrations of 2,4-D and kinetin and effect of source of spikes. The results indicated that the cold pretreatment had no effect on anther response of three wheat varieties, the chemical pretreatments by sterilization substances (ethanol alcohol $70 \%$ or mercurec chloride $1 \mathrm{~g} / \mathrm{L}$ or thiourea $2 \mathrm{~g} / \mathrm{L}$ ) were very important and essential to induce callus from anther. The three treatments of ( $1 \mathrm{mg} / \mathrm{L} 2,4-D),(2 \mathrm{mg} / \mathrm{L} \mathrm{2,4-D})$ and $(2 \mathrm{mg} / \mathrm{L}$ 2,4-D + $0.1 \mathrm{mg} / L$ kinetin) gave the highest response of callus induction and plant regeneration. Androgenesis improved with increasing the cultured area which the spikes were collected from it . Key words: Wheat, Anther culture, Cold \& chemical Pretreatments, Growth regulators, Effect of source of spikes, Varieties.

\section{INTTRODUCTION}

Wheat is considered the second cereal crop after rice in response to in vitro androgenesis. However, the frequency of response in general worldwide ranged from $0-70 \%$, some lines had high frequency (Bajaj 1990), so increasing frequency is the ultimate goal. Albino plants is a serious problem associated with anther culture in cereal crops (Bajaj, 1990). Most researchers consider the cold pretreatment is very important to induce the callus formation during anther plating process ( Barcelo et al., 1994; Stober et al., 1997; Ohnoutkova et al., 2001; Polci et al., 2005 and Duran and Savaskan, 2011), on other hand, some researchers reported that the cold pretreatment is not always needed (Xynias et al., 2001), low temperature pretreatment had a negative effect on the embryiod and green plant number in most of the cultivars (Zamani et al., 2001). Researchers 
believe that the cold pretreatment of anther act as a stress on wheat spikes whenever they use another strongest pretreatment when they sterilize the spikes with chemical compounds, so we must separate the cold and the chemical pretreatments, this can be applied during anther culture process without sterilization, especially the spikes is covered with the leaf sheath at booting stage. The auxin of 2,4-D is essential for androgenesis ( Bajaj 1990; Hassawi et al., 1990; Ball et al., 1993 and Saeed et al., 1994). The highest variance was found among the spikes of different plants so the spikes must be collected from a wide area planted with variety, spike to spike variation appeared to be a heritable character (Dunwell et al., 1987). Androgenesis is variety dependant (Haggag and El- Hennawy 1996; Hassawi et al., 2005; Zamani et al., 2003; Barakat et al., 2012; Rizkalla et al., 2012 and AL - Ashkar, 2013).

So, this research was undertaken to study the effect of some pretreatments of anther culture on callus induction and establishment a technique to obtain haploid plants.

\section{MATERIALS AND METHODS}

This study was practiced at Plant Biotechnology Department, Genetic Engineering and Biotechnology Researches Institute (GEBRI), Sadat City, University Menufiya, Egypt. The main objective of this study was produce haploid plants by anther culture .Seeds of three Egyption wheat varieties, Sids 1, Gemmeiza 9, and Giza 168 were obtained from Agriculture Research Station, Gemmeiza, Tanta, Gharbiya, Egypt, and sown at plots 6 sq. m per each variety at the Experimental Farm of (G EBRI). Spikes were collected at booting stage when the awn first emerged and just before the sheath opening, this morphological shape indicate the uninuclate stage in development of pollen grains . Leaves were removed from spikes and the stems were cut at $4 \mathrm{~cm}$ below the first node prior to the spike. Spikes were washed with tap water and dried with paper towel . Spikes were covered with aluminum foil and kept at $3 \pm 1 \mathrm{C}^{\circ}$. Before inoculation at laminar flow hood, spikes were immersed in ethanol alcohol $70 \%$ for six hours at $5^{\circ}$ at just below the first node prior to the spike except (the experiment of cold pretreatment ).All experiments were carried out without sterilization. Spikes were pulled from the sheath carefully, anthers were excised and plated at jars each one contain $20 \mathrm{ml}$ of induction medium (modified MS medium+2 $\mathrm{mg} / \mathrm{L}$ 2,4-D+0.1 $\mathrm{mg} / \mathrm{L}$ kin+90g maltose), solidified with $6 \mathrm{~g}$ agar, 50 anther/ jar. ten replicates from each treatment were used. The anther culture medium used in this study was based on published work in wheat (Henry and De Buyser, 1985) with some 
modification regarding to the kind and concentration of sugar and growth regulators.

Inoculated jars were incubated under dark condition at $26 \mathrm{C}^{\mathrm{o}}$ for 4 weeks, then jars with swelling anthers were transferred to the light . After two weeks jars were examined for callus induction, after about 4 weeks from callus initiation and callus stop growth, then the anther wall changes to white brown membranous because of depletion of the nutration from the anther wall. Then obtained calli were transferred to the regeneration medium (MS+0.2 $\mathrm{mg} / \mathrm{L} \mathrm{BA}+200 \mathrm{mg} / \mathrm{L}$. glutamin+30 g sucrose), the regenerates were counted.

\section{The studied treatments:-}

1- Cold pretreatment: Spiks were kept at $3 \pm 1 \mathrm{C}^{0}$ for $4,8,12,16,20,24$ and 28 (days) before inoculation at modified MS medium $+2 \mathrm{mg} / \mathrm{L} 2,4-\mathrm{D}$ $+0.1 \mathrm{mg} / \mathrm{L}$ kinetin $+90 \mathrm{~g} / \mathrm{L}$ maltose .

2 - Chemical pretreatments: Spikes were immersed in (Ethanol alcohol $70 \%$ or mercurec chloride $1 \mathrm{~g} / \mathrm{L}$ or thiourea $2 \mathrm{~g} / \mathrm{L}$ ) for 3,6 and 9 hours at $5 \mathrm{C}^{\mathrm{o}}$ before inoculation at modified MS medium $+2 \mathrm{mg} / \mathrm{L} 2,4-\mathrm{D}+0.1$ $\mathrm{mg} / \mathrm{L}$ kinetin $+90 \mathrm{~g} / \mathrm{L}$ maltose .

3- Growth regulators: Anthers were plated on induction medium( modified MS medium with combination of $0,0.5,1.0,2.0$ and $3.0 \mathrm{mg} /$ $\mathrm{L} \quad 2,4-\mathrm{D}$ and $(0,0.1$ and $0.2 \mathrm{mg} / \mathrm{L} \mathrm{kin})+90 \mathrm{~g} / \mathrm{L}$ maltose .

4- Source of spikes: Spikes were collected from three sources ( A, B and C).

(A) Plots which sown with seeds from harvesting the plots of the last year.

(B) Plots which sown with seeds from Agriculture Research Station.

(C) Open field which sown with the same varieties.

Anther from the previous three sources of three wheat varieties were plated at modified MS medium $+2 \mathrm{mg} / \mathrm{L} \mathrm{2,4-D}+0.1 \mathrm{mg} / \mathrm{L}$ kinetin + $90 \mathrm{gm} / \mathrm{L}$ maltose.

\section{RESULTS AND DISCUSSION}

1- Effect of cold pretreatment period at $3 \pm 1 C^{0}$ on anther response (callus count \%) of wheat varieties:

The results in Table 1 show the effect of cold pretreatment at $3 \pm 1 \mathrm{C}^{\circ}$ period on anther response of the studied wheat varieties. All cold pretreatments had no effect on anther response of the three wheat varieties , these results may be attributed to the cold pretreatment do not act as a stress as enough to switch on the genes which were responsible for the embryogenic pathway at microspores. Unsuitable pretreatments hide the effect of medium and varieties. These results were in contrast with those 
Table 1 : Effect of cold pretreatment period at $3 \pm 1 C^{0}$ on anther response (callus count \%) of wheat varieties.

\begin{tabular}{|c|c|c|c|}
\hline \multirow{2}{*}{$\begin{array}{c}\text { Cold } \\
\text { Pretreatment } \\
\text { Period /day }\end{array}$} & \multicolumn{3}{|c|}{ Varieties } \\
\hline & Sids 1 & Gemmeiza 9 & Giza 168 \\
\hline 4 & $\mathbf{0}$ & $\mathbf{0}$ & $\mathbf{0}$ \\
\hline 8 & 0 & $\mathbf{0}$ & 0 \\
\hline 12 & $\mathbf{0}$ & $\mathbf{0}$ & $\mathbf{0}$ \\
\hline 16 & 0 & 0 & (0 \\
\hline 20 & $\mathbf{0}$ & $\mathbf{0}$ & (0 \\
\hline 24 & $\mathbf{0}$ & $\mathbf{0}$ & $\mathbf{0}$ \\
\hline 28 & $\mathbf{0}$ & (0) & $\mathbf{0}$ \\
\hline
\end{tabular}

obtained by most or nearly all researchers (Barcelo et al., 1994; Stober et al., 1997; Ohnoutkova et al., 2001; Xynias et al., 2001; Zamani et al., 2001; Bolci et al., 2005 and Duran and Savaskan, 2011).

\section{2- Effect of chemical pretreatments on anther response (callus count $\%$ and regeneration \%) of wheat varieties:}

Data in Table 2, refer to the effect of chemical pretreatments on anther response (callus count, \% and regeneration, \%) of the studied wheat varieties. Immersion the stems of the spikes for six hours in $\left(\mathrm{C}_{2} \mathrm{H}_{5} \mathrm{OH}\right.$ or $\mathrm{Hg} \mathrm{Cl}_{2}$ or $\mathrm{CH}_{4} \mathrm{~N}_{2} \mathrm{~S}$ ) was the only suitable period to induce the embryogenic pathway at microspores. Ethanol alcohol is considered the relatively best chemical pretreatment in comparison to the other two chemical pretreatments, however, it recorded the highest callus count and regeneration percentages for the studied wheat varieties followed by mercurec chloride and thiourea. Every one used sterilization is considered used the previous chemical pretreatments. The variety Gemmeiza 9 is considered the best of these varieties in both callus count and regeneration percentages followed by Giza 168 and Sids1 however the regeneration is ultimate goal.

Microscopically examination of pollen grains after 3, 6 and 9 hours from immersion in ethanol alcohol (Figure 1b) showed that after 3 hours, all pollen grains were at good status and completely spherical shape (Figure 1a), but after 6 hours about $50 \%$ or more of pollen grains were shrinkin (dead), and another $50 \%$ or less of pollen greens were at good status (Figure 1c), while at 9 hours all pollen grains were shrinkin. We can say that the induction is between the life and the death of pollen grains and sterilization with chemical substances do as sterilization and induction. 
Table 2 : Effect of chemical pretreatments on anther response (callus count $\%$ and regeneration $\%$ ) of wheat varieties .

\begin{tabular}{|c|c|c|c|c|c|}
\hline \multicolumn{2}{|c|}{ Treatments } & \multirow{2}{*}{\multicolumn{3}{|c|}{$\begin{array}{c}\begin{array}{c}\text { Callus count } \\
\%\end{array} \\
\text { Immersion time } \\
\end{array}$}} & \multirow{3}{*}{$\begin{array}{c}\text { Regeneration } \\
\%\end{array}$} \\
\hline \multirow[t]{2}{*}{ Variety } & \multirow{2}{*}{$\begin{array}{c}\text { Chemical } \\
\text { pretreatments }\end{array}$} & & & & \\
\hline & & $(3)$ & $(6)$ & (9) & \\
\hline \multirow{3}{*}{ Sids 1} & $\overline{\mathrm{C}_{2} \mathrm{H}_{5} \mathrm{OH}}$ & 0 & 1.2 & 0 & 0 \\
\hline & $\mathrm{Hg} \mathrm{Cl}_{2}$ & 0 & 0.8 & 0 & 0 \\
\hline & $\mathrm{CH}_{4} \mathrm{~N}_{2} \mathrm{~S}$ & 0 & 0.8 & 0 & 0 \\
\hline \multirow{3}{*}{$\begin{array}{c}9 \\
\text { Gemmeiza }\end{array}$} & $\overline{\mathrm{C}_{2} \mathrm{H}_{5} \mathrm{OH}}$ & 0 & 1.6 & 0 & 160 albino plants \\
\hline & $\mathrm{Hg} \mathrm{Cl}_{2}$ & 0 & 0.8 & 0 & $\begin{array}{c}100 \text { partial } \\
\text { regeneration }\end{array}$ \\
\hline & $\mathrm{CH}_{4} \mathrm{~N}_{2} \mathrm{~S}$ & 0 & 0.8 & 0 & 0 \\
\hline \multirow[t]{3}{*}{ Giza 168} & $\overline{\mathrm{C}_{2} \mathrm{H}_{5} \mathrm{OH}}$ & 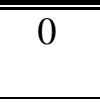 & 0.4 & $\overline{0}$ & $\begin{array}{l}100 \text { partial } \\
\text { regeneration }\end{array}$ \\
\hline & $\mathrm{Hg} \mathrm{Cl}_{2}$ & 0 & 0.4 & 0 & 0 \\
\hline & $\mathrm{CH}_{4} \mathrm{~N}_{2} \mathrm{~S}$ & 0 & 0.4 & 0 & 0 \\
\hline
\end{tabular}

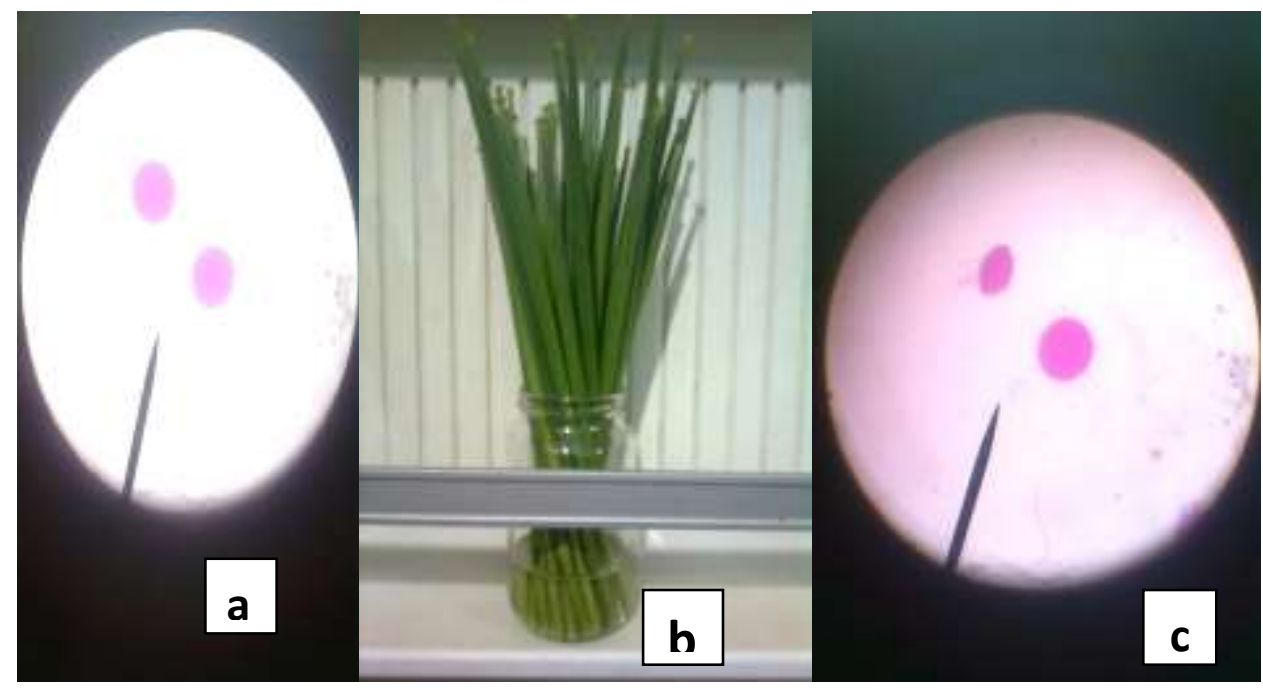

Figure 1. Chemical pretreatment and microscopically examination

\section{3- Effect of growth regulators on anther response (callus count \% and} regeneration \%) of wheat varieties: .

Results in Table 3 show callus count and regeneration percentages of the studied wheat varieties as affected by growth regulators concentration. 
The common observation of data at Table 3, was the frequency of anther response of the three wheat varieties is very low and the regenerates are albino, these results may be due to collecting the spikes from a small cultured area (plots which were sown with seeds from Agriculture Research Station ) and the variance among the small number of plants is low. The very low frequency leads to the effect of some treatments appear in one year and disappear in another year because of when the spikes which would response to anther culture were lost we don,t find instead of them and also leads to low response and albino plants (Figure 3a,b,c \&d), when the variance is high it will gave the chance to increasing the frequency and the green plants exhibit ( Figure 3e). Generally the three concentrations (1mg/L 2,4-D), (2 mg /L 2,4-D ) and (2 mg /L 2,4-D + 0.1

Table 3: Effect of growth regulators on anther response (callus count $\%$ and regeneration $\%$ ) of wheat varieties.

\begin{tabular}{|c|c|c|c|c|c|c|c|}
\hline \multicolumn{2}{|c|}{ Treatments } & \multicolumn{6}{|c|}{ Varieties } \\
\hline \multirow{2}{*}{$\begin{array}{l}\text { Kin } \\
\text { mg/L }\end{array}$} & \multirow{2}{*}{\begin{tabular}{|l|}
$2,4-D$ \\
$\mathrm{mg} / \mathrm{L}$
\end{tabular}} & \multicolumn{2}{|c|}{ Sids 1} & \multicolumn{2}{|c|}{ Gemmeiza9 } & \multicolumn{2}{|c|}{ Giza 168} \\
\hline & & $\begin{array}{c}\text { Callus } \\
\text { Count } \\
\%\end{array}$ & $\begin{array}{l}\text { Regeneratio } \\
\text { n \% }\end{array}$ & $\begin{array}{c}\text { Callus } \\
\text { Count } \\
\%\end{array}$ & $\begin{array}{c}\text { Regeneration } \\
\%\end{array}$ & $\begin{array}{c}\text { Callus } \\
\text { Count } \\
\%\end{array}$ & $\begin{array}{c}\text { Regeneration } \\
\%\end{array}$ \\
\hline \multirow{5}{*}{0.0} & 0.0 & $\overline{0}$ & $\overline{0}$ & $\bar{~} 0$ & $\overline{0}$ & 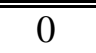 & $\overline{0}$ \\
\hline & 0.5 & 0 & 0 & 0 & 0 & 0 & 0 \\
\hline & 1.0 & 0.8 & 100 albino & 0.8 & 0 & 0 & 0 \\
\hline & 20 & 0.8 & 0 & 0.8 & 100 albino & 0 & 0 \\
\hline & 3.0 & 0 & 0 & 0 & 0 & 0 & 0 \\
\hline \multirow{5}{*}{0.1} & 0.0 & 0 & 0 & 0 & 0 & 0 & 0 \\
\hline & 0.5 & 0 & 0 & 0 & 0 & 0 & 0 \\
\hline & 1.0 & 0 & 0 & 0 & 0 & 0 & 0 \\
\hline & 2.0 & 1.2 & 0 & 1.6 & 160 albino & 0 & 0 \\
\hline & 3.0 & 0 & 0 & 0 & 0 & 0 & 0 \\
\hline \multirow{5}{*}{0.2} & 0.0 & 0 & 0 & 0 & 0 & 0 & 0 \\
\hline & 0.5 & 0 & 0 & 0.4 & 0 & 0 & 0 \\
\hline & 1.0 & 0.8 & 0 & 2.0 & 0 & 0 & 0 \\
\hline & 2.0 & 0.8 & 0 & 1.6 & 50 frible callus & 0 & 0 \\
\hline & 3.0 & 0 & 0 & 0.0 & 0 & 0 & 0 \\
\hline
\end{tabular}



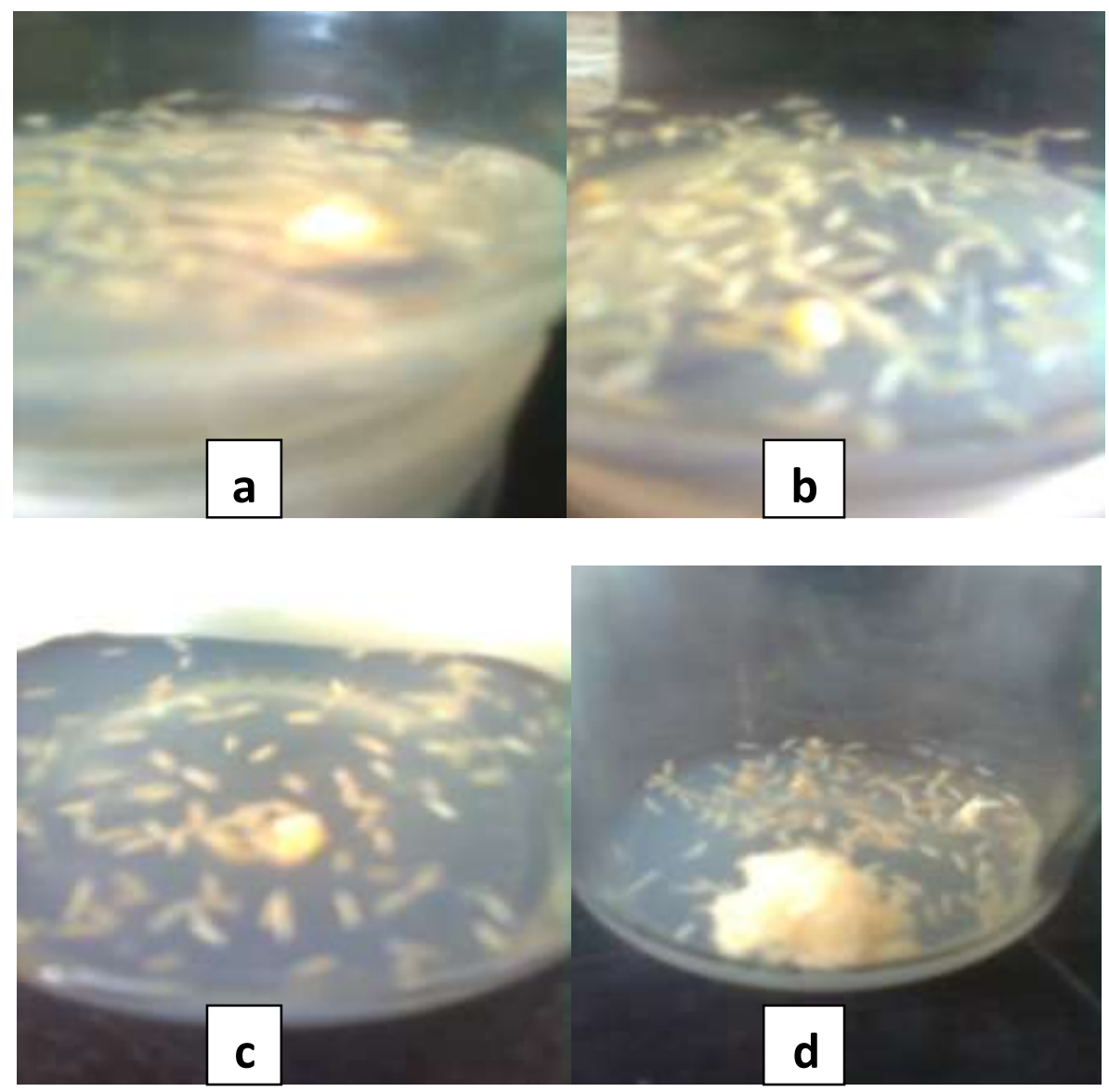

Figure 2: Callus of anther

$\mathrm{mg} / \mathrm{L}$ kinetin) recorded the best results for callus count and regeneration percentages for the three wheat varieties. Gemmeiza 9 variety was the superior of these varieties at callus count and regeneration percentages but Giza 168 was the lowest one and Sids1 is the intermediate. Without 2,4-D androgenesis don't happen, these results are in agreement with those obtained by (Hassawi et al., 1990, Ball et al., 1993 and Saeed et al., 1994). The cell behavior depend on the balance between the endo and the exo hormones, the low concentration of 2,4-D was not enough to elongation and division of pollen grains but at high concentration of 2,4-D the cell elongate without division and the toxcisity of 2,4-D exhibit. 

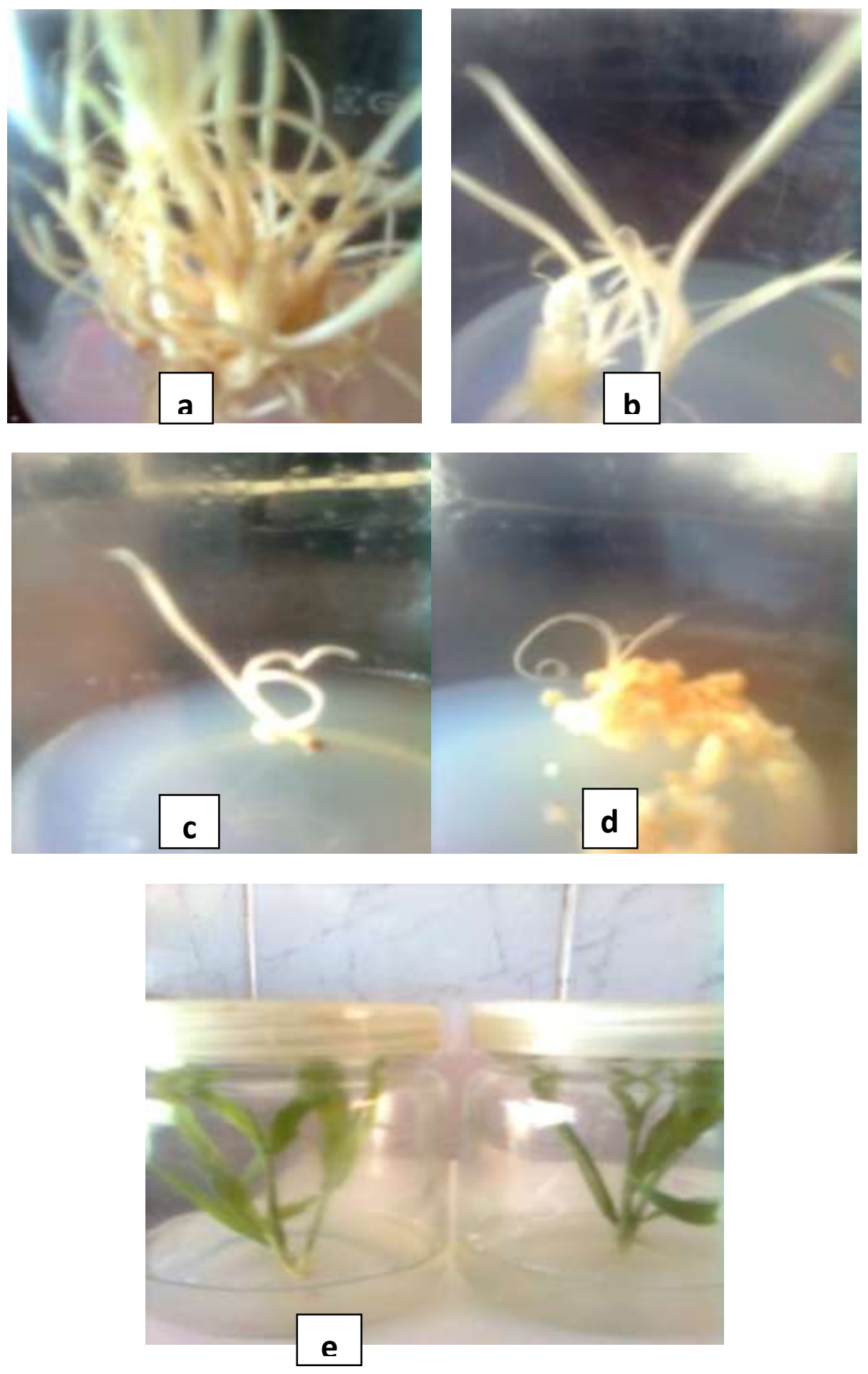

Figure 3: Regeneration of anther callus 


\section{4- Effect of source of spikes on anther response (callus count \% and regeneration \%) of wheat varieties:}

Data in Table 4, clear that anther callus and regeneration percentage as affected by wheat varieties and source of spikes.

Spikes of wheat variety Gemmeiza 9 which obtained from source $\mathrm{C}$ produced the highest percentage of callus count (2.8\%) followed by spikes of Sids1 variety from source C , spikes of Gemmeiza 9 variety from source B (1.6\%). On the other hand spikes of Giza 168 variety from source A have (Zero \%) of callus count. Gemmeiza 9 variety surpass the other varieties in callus count percentage meanwhil Giza 168 variety was the last. From the same Table 4, regeneration percentage of Gemmeiza 9 variety, spikes from source $\mathrm{C}$ recorded the highest percentage of regeneration 168\% (126\% albino plants $+42 \%$ green plants as shown in Figure 3) followed by spikes from source B of the same variety $150 \%$ regeneration. On the other side spikes of wheat variety Sids1 from source A have (zero\%) regeneration. Also Giza 168 variety do not regenerate to plants, this could be the regeneration is higher heritability character than callus formation. These results were in agreement with those obtained by (De Buyser and Henary, 1979; Dunwell et al., 1987; Petolino and Thompson, 1987 and Ockendon and Sutherland, 1987). From these results, callus count and regeneration percentages differed according to wheat variety and spikes source, while as the selection area of spikes increased callus count increased and the regeneration improved however the green plants exhibit.

Table 4: Effect of source of spikes on anther response (callus count $\%$ and regeneration \%) of wheat varieties.

\begin{tabular}{|c|c|c|c|}
\hline \multicolumn{2}{|c|}{ Treatments } & \multirow[b]{2}{*}{$\begin{array}{c}\text { Callus count } \\
\%\end{array}$} & \multirow[b]{2}{*}{$\begin{array}{c}\text { Regeneration } \\
\%\end{array}$} \\
\hline Varieties & Source of spikes & & \\
\hline \multirow{3}{*}{ Sids 1} & $\mathbf{A}$ & 0.4 & 0 \\
\hline & B & 1.2 & 99 albino plants \\
\hline & $\mathbf{C}$ & 2.0 & 99 allbino plants \\
\hline \multirow{3}{*}{ Gemmeiza 9} & $\mathbf{A}$ & 1.2 & 99 albino plants \\
\hline & B & 1.6 & 150 albino plants \\
\hline & $\mathbf{C}$ & 2.8 & $\begin{array}{l}126 \text { albino plants } \\
42 \text { green plants } \\
\end{array}$ \\
\hline \multirow{3}{*}{ Giza 168} & $\mathbf{A}$ & $\mathbf{0}$ & 0 \\
\hline & B & 0.8 & $\mathbf{0}$ \\
\hline & $\mathrm{C}$ & 1.2 & $\mathbf{0}$ \\
\hline
\end{tabular}


A : Plots which were sown with seeds from harvesting plots of the last year .

B : Plots which were sown with seeds from Agriculture Research Station .

C: Open field which were sown with the same varieties .

\section{REFERENCES}

AL-Ashkar, I. M. ( 2013 ). Anther culture response and salt tolerance in some wheat genotypes. Annals of Agric Sci., 58(2): 139 - 145.

Ball S, T.; A. P. Zhou and C. F. Konzak (1993). Influence of 2,4-D , IAA and duration of callus induction in anther culture of spring wheat . Plant Science (Limerick), 90(2): 195 - 200.

Bajaj, Y. P. S. ( 1990 ). Haploid in crop improvement. Vol. 12(encyclopedia)

Barakakat, M . A ; A . AL - Doss ; A . Elshafei ; K . Moustafa and E .

Barcelo, P ; C . Cabrera ; C . Hagel and H . Loerz ( 1994). Production of doubled haploid plants from tritordum anther culture. Theor and Appl Genet 87 ( 6) 741- 745 .

De Buyser, J and Henry (1979). Androgenesis sur des Bles tendres en cours de selection, I. l'obtenttion des plantes in vitro. Zpflanzenzucht, 83: 997- 1000.

Duran R., E. and C. Savaskan (2011). Salinity tolerance of Durum wheat genotype in androgenesis . Gazi Unive Journal of Science 24 (4) 657 662.

Dun well, J . M ; Francis R . I and Powell .W ( 1987). Anther culture of Hordeum vulgare L . : A genetic study of microspore callus production and differentiation . Theor Appl Genet, 79: 60 - 64.

Haggag , M . E and M . A . EL - Hennawy (1996). Anther culture of Egyption wheat cultivars . Annals of Agric . Sci Ain Shams Univ. Cairo, 41(2): 739 -759.

Hassawi, D. S ; L. J. Qi and H. G. Liang (1990). Effect of growth regulator and genotype on production of wheat and tritical polyhaploids from anther culture . Plant Breeding, 104(1): 40-45.

Hassawi, D. S. ; I. Qrunfleh and N. Dradkah (2005).Production of doubled haploiod from some jordanian wheat cultivars via anther culture technique . Journal of Food, Agric and Environ., 3(1): 161 - 164.

Henry, Y and J . de Buyser ( 1985). Effect of the IB/IR translocation on the anther culture ability in Wheat ( Triticum aestivum L.) Plant Cell Rep 4: 307- 310.

Ockendon, D J and R . A . Sutherland (1987). Genetic and non - genetic factors affecting anther culture of Brussels Sprouts ( Brassica oleracea var.). Theor Appl Genet, 74: 566 - 570. 
Ohnoutkova, L. ; J. Novotmy ; E. Mullerova ; J. Vagera ; 1. Kucera and B. B. Ohnec (2000). Is a cold pretreatment really needed for in vitro androgenesis in barly and wheat. Biotechnological- approaches- for utilisation of gametic cells cost. 824 final -Meeting- Bled-Solvena1-5 - July 2000 - 2001, 33-37.

Petolino J. F. and S. A. Thompson (1987). Genetic analysis of anther culture response in maize. Theor. Appl. Genet, 74: 284-286.

Polci , P ; V. Conti ; G. Aldoa Humble ; R. Miranda and V. Echenique ( 2005 ) Haploid plant production from argantinian genotypes of bread wheat ( Triticum aestivum L.) through anther culture and intergenic crosses .RIA, Revista de investigac Agropecu, 34 (3): 151 - 176.

Rizkalla, A. A. ; A. M. F. Al- Ansary ; S. A. A. Attia ; A. A. A. Haiba and J. E . Nasseef (2012). Response of some Egyption and introduced wheat hybrids to androgenic process. International Journal of Agriculture Research, 7 (4): 205 - 214.

Saeed, N. A. ; M. A. Chowdhry and I. A. Khan (1994 ). Induction of callus and organogenesis in bread wheat through anther culture. Pakistan J. Agric-Res., 15 (1).

Stober, A and D . Hess (1997). Spike pretreatment, anther culture conditions, and anther culture response of 17 German varieties of spring wheat (Triticum aestivum L.). Plant Breeding, 116 (5): 443-447.

Xynias, I. N ; I. A. Zamani ; E. S. Vavdinoudi and D. G. R. Oupakias (2001). Effect of cold pretreatment and incubation temperature on bread wheat anther culture. Cereal Res Commun, 29 (3- 4): 331338.

Zamani, I. ; E . Couli- Vavdinoudi and D . G . Roupakias ( 2000 - 2001 ) production of doubled haploid in wheat ( Triticum aestivum ). Biotechnological approaches for utilisation of gametic cells Cost 824 : 1-5 2000 - 2001, $43-51$.

Zamani, I. ; E. Couli ; E. Vavdinoudi ; G. Kovacs ; I. Xynias ; D. Roupakias and B. Barnabas ( 2003 ). Effect of parental genotypes and colchicine treatment on the anther androgeneic response of wheat. Plant Breed, 122( 4 ): 314 - 317. 


\section{إنتاج نباتات أحاديه بإستخدام تقنية زراعة المتك فى القمح}

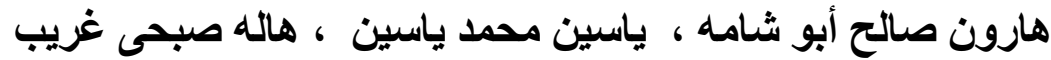

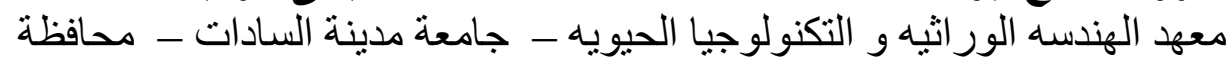
المنوفيه - معند المنده

أجريت أربعة تجارب بين المزر عه التجريبيه و معامل قسم البيوتكنولوجيا النباتيه ،

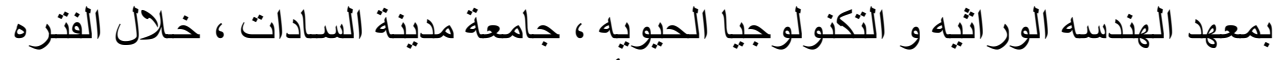

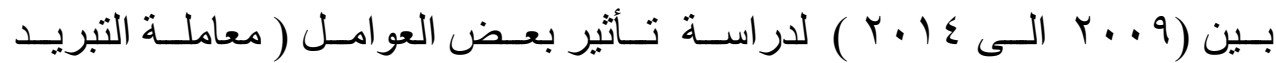

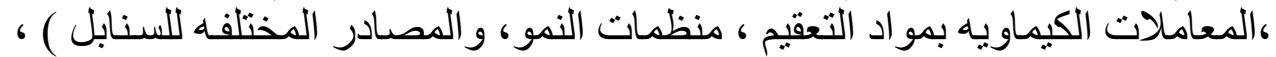

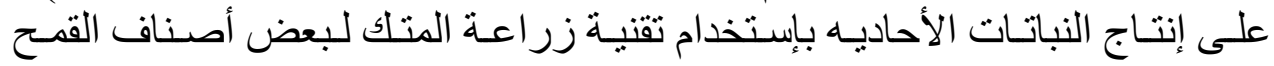

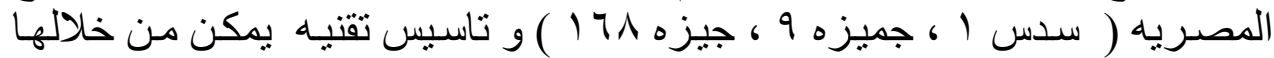
الحصول على النباتات الأحاديه

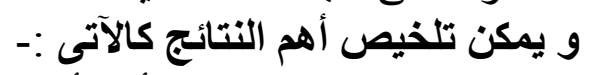
لم يكن لمعاملة التبريد أى تأثير على : التى تحفيز المتلك لتكوين الكالس.

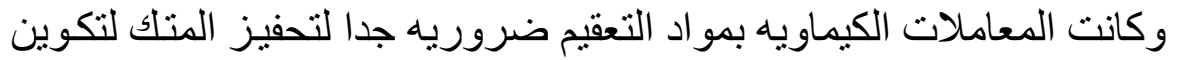

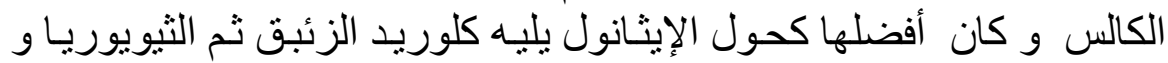
ذلك عند 7 ساعات فقط من الغمس.

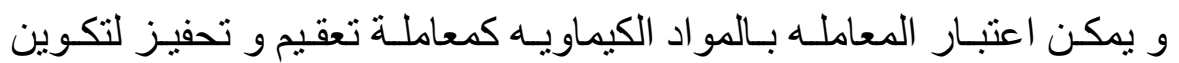

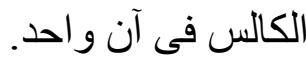

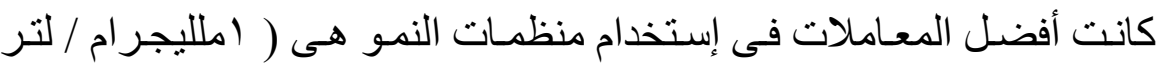

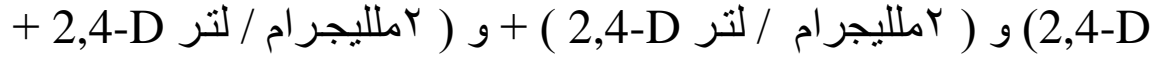
او ملاليجر ام / لتر كينتين ).

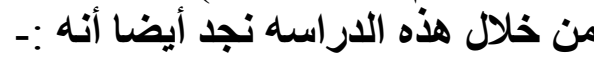

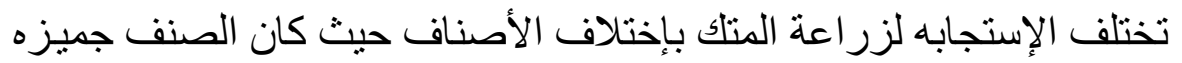

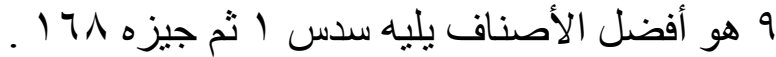

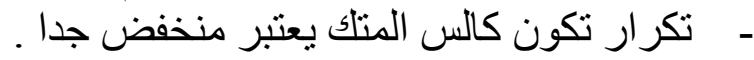

